\title{
Free Theological/Biblical Resources on the Web
}

presented by Matt Gray;

compiled by Wendy Davis, using notes from

Rosemary Hocking and Barbara Cooper

\section{http://e-sword.net}

Free, downloadable software (version 10). This basic installation includes the King James Version, King James Version w/ Strong's numbers, Strong's dictionary, and the Treasury of Scripture Knowledge cross-references. Download additional resources using the "Download" menu within e-Sword. Includes Parallel bibles, integrated editor, Strong's tooltips, Scripture tooltips, powerful searching, reference library, graphics viewer, audio sermons and user guide.

\section{http://www.biblegateway.com}

Searchable Bible texts. Includes:

- over 40 English versions as well as 70 languages (includes Greek, Hebrew, Latin, European languages, Maori, Vietnamese, Somali and many more).

- Audio Bibles in 6 English versions and 8 other languages

- Commentaries (IVP and Matthew Henry)

- Ebook versions of the Bible

- Dictionaries

- Mobile phone app

- Devotionals and reading plans

- Bible Gateway blog

\section{http://greekbible.com}

The Online Greek Bible

- Search and look up New Testament passages

- Browse and order printed biblical and classical Greek study materials

- Access resources around the web to help you learn and study ancient Greek

\section{http://www.theologyontheweb.org.uk/}

Theology on the Web

"Aims to make high quality theological material available throughout the world, thus providing Bible teachers and pastors with the resources they need to spread the Gospel in their countries. This is achieved by: 
- Digitising and uploading in co-operation with authors and publishers, rare and out-ofprint theology books and articles. Over 18,000 articles are now available for free download.

- Providing detailed bibliographies for Seminary level students and ministers."

Theology on the Web is a single cross-linked resource made up of the following websites:

1. BiblicalStudies.org.uk hosts over 18,000 full text theological articles linked into bibliographies on each book of the Bible. It also covers such subjects as hermeneutics, biblical languages, criticism, language, etc. - in short almost everything connected with the Bible and its study.

2. TheologicalStudies.org.uk throws its net slightly wider, providing material on a range of theologies and theologians, as well as specific doctrines such as the Trinity, for example. The section on practical theology seeks to provide material on how theology is applied in daily life, in such areas as politics and ethics.

3. EarlyChurch.org.uk covers church history until the rise of the medieval Papacy (c.600 $\mathrm{AD})$.

4. MedievalChurch.org.uk takes over where EarlyChurch.org.uk leaves off, covering church history from the rise of the Papacy to the time of the Reformation.

5. ReformationChurch.org.uk - covers church history during and after the Reformation.

6. BiblicalArchaeology.org.uk provides material relating to the archaeology of the lands of the Bible.

7. Missiology.org.uk provides resources for students of Christian missions from the first Century onwards [currently under development].

http://www.ccel.org

Christian Classics Ethereal Library: bringing Christian classic books to life. The CCEL is a digital library of hundreds of classic Christian books selected for edification and education.

It includes works from a variety of viewpoints and traditions that are in the public domain. Searchable by title, author, LC subject, and user selected subject tags. Users also have access to site forums and study groups.

\section{http://archive.org}

Offers permanent access for researchers, historians, scholars, people with disabilities, and the general public to historical collections that exist in digital format. The Internet Archive includes: texts, audio, moving images, and software as well as archived web pages, and provides specialized services for adaptive reading and information access for the blind and other persons with disabilities.

http://books.google.com

Includes full text, limited and snippet views. Books are sourced from the Partner Program http://books.google.com/intl/en/googlebooks/partners/ and the Library Project http://books.google.com/int1/en/googlebooks/library/. Full text of books in the public domain, or to which the publisher has given permission, are available. Google's database includes more than 30 million scanned books and magazines.

http://www.nla.gov.au

Access the collections of the National Library including their online resources.

1 http://www.theologyontheweb.org.uk/, accessed December 02, 2013. 
http://trove.nla.gov.au/

"With millions of items, Trove is an unrivalled repository of Australian material. Trove is for all Australians. Whether you are tracing your family history, doing professional research, reading for pleasure, teaching or studying, Trove can help."

Trove is the distributed national collection, and more, providing information on the holdings of many Australian libraries. Also includes digitized Australian newspapers, music, sound and video, pictures, photos, maps, archived websites, diaries, letters, archives, and of course, books and journals.

2 http://trove.nla.gov.au/, accessed December 02, 2013. 